\title{
A Development of Learning Management Skills of Student Teachers in Cooperative Schools
}

\author{
Kancheera Onkwanmoung
}

\begin{abstract}
The objectives of this research are: 1) to develop learning management skills of student teachers in cooperative schools; and 2) to improve learning achievement of student. The populations used in this research were 200 student teachers in five cooperative schools of Academic Year 2013, especially Thai language student teachers in cooperative schools where the researcher was working as the university supervisor for 11 student teachers. The results showed that: 1) After receiving student teacher's professional teaching practice, the student teachers were developed on learning management skills regarding lesson plan preparation, and learning management process. After measuring their performance, it was found that their ability on learning management was improved in high level. 2) Development of teacher professional skills enabled Thai language student teachers to have learning achievement in high level.
\end{abstract}

Index Terms - Learning management skills, student teachers practicum.

\section{INTRODUCTION}

Section 52 of Article 6, Educational Standards and Quality Assurance, of National Education Act B.C. 1999 and defines that "The Ministry shall promote development of a system for teachers and educational personnel, including production and further refinement of this category of personnel, so that teaching will be further enhanced and become a highly respected profession. The Ministry, shall, in this regard, take a supervisory and coordinating role so that the institutions responsible for production and development of teachers, faculty staff, and educational personnel shall be ready and capable of preparing new staff and continually developing in-service personnel [1]."

According to those acts, teaching professional standards and quality are emphasized and teaching profession is considered as the advanced profession. As a result, teaching professional practice is greatly the key of teaching professional learning. Consequently, all institutes with teacher production should provide the opportunity to all student teachers for practicing teaching profession systematically, continuously, and seriously in order to obtain the teachers who are the educational quality assurance of Thailand in the future. As a result, the concept of teacher production defines the result of teacher production as building "quality" or "ability". It is defined as the teacher's capacity and quality that teacher should be the master teacher who is

Manuscript received November 26, 2014; revised February 3, 2015.

Kancheera Ontkwanmoang is with the Faculty of Education of Suan Sunandha Rajabhat University, Thailand (e-mail: kancheera.on@ssru.ac.th). happy with his/her profession [2]. We may say that master teacher is a teacher who possesses spirituality in teachers, realizes his/her responsibilities, sacrifices, be a good model, possesses professional quality standards of advanced profession, specializes in sciences and art of being a professional teacher commencing from lesson plan preparation, learning management process, measurement and assessment of learning. As a result, teacher's learning management skills development is very important [3].

For teacher production curriculum of Suansunandha University, the period of learning management and student teacher development was 5 academic years [4]. All fifth year student teachers were stipulated to practice teaching profession for one year prior their graduation in order to provide them an opportunity to gain some experiences and skills of teaching profession through experimenting all principles, methods, and theories of educational management, concepts on learning management, instructional guidelines obtained from university for utilizing in actual situations. In addition, they also had a direct experience on performing all responsibilities and duties as the teachers as well as had understanding on natures and development of student teacher's learning upon their age. Moreover, they also had an opportunity to develop teacher's potential and human relations for working with other people including administrators, university supervisors, university teachers, colleagues, students, and other personnel [5]. They also had an opportunity to learn and understand their weaknesses and strengths creatively and be ready to develop, improve, study, and understand the condition of their community. Finally, they had an opportunity to practice their participatory performance skills in their community sustainably (Council of Teaching Profession) [6].

Practicing of student teachers was started in the cooperative schools and student teachers had to behave themselves as the professional teachers who had to perform all responsibilities of teaching profession. Their important duty was practicing classroom teaching experience with students who were in basic education level. The university compared student's performance equal to registration of 16 credits of university's learning divided into 2 semesters with 8 credits per semester with no registration of other subjects except for any necessary case requiring the permission from the university case by case. The standard was defined that a student teacher shall earn at least 12 hours of teaching experience per hour in the practice school during one semester. In the event that any student teacher fails to complete such duration of teaching experience, such student teacher had to have more burdens of teacher including learner development activities, boy scout and girl guide activities, or 
other activities., with calculated duration equal to the missing duration (Student Guideline of Suansunandha University, 2012) [7].

Since the researcher had been a university supervisor for 9 years, the research discovered some empirical data exhibiting that over than a half of student teachers were worried whether they would be unable to perform their teaching responsibilities according to the capacity defined by Teacher Council of Thailand after being assigned to the practice schools [8]. According to observation recording in the first period of supervision of teaching, the mostly found problem was excitement of student teachers in behaving towards their students followed by the problem of no improper understanding on lesson plan preparation through considering on quality and goals according to terms in standards and indicators of each subject and classroom, the problem of incapability to integrate knowledge and skills with learning management process mainly emphasizing on learners, and the problem of instructional media preparation or selection as well as examination of instructional media quality or creation of innovation consistent with learning management process. Finally, the problem of the use of techniques and strategies with learning management, measurement and assessment of actual learning results, utilization of assessed results for developing learning management and learner quality development, etc [9].

Consequently, the researcher was interested in developing the capacity on learning management that was the important capacity of teachers influencing on learner quality through development of learning management skills of the student teachers in cooperative schools in order to develop learners because teachers play the important role in developing educational quality o meet with expectation and intention on developing Thai youth to be the good and efficient Thai citizens for building stability and prosperity of Thailand.

\section{OBJECTIVES}

1) To develop learning management skills of student teachers in cooperative schools.

2) To improve learning achievement of student taught by student teachers.

\section{HYPOTHESIS}

The result of learning management testing of student teachers in cooperative schools in post-development stage was higher than that of pre-development stage.

The student teachers in cooperative schools were satisfied with development of their learning management skills in high level.

Students in the classrooms taught by the student teachers had higher level of learning achievement.

\section{SCOPE OF RESEARCH}

Populations used in this research were 200 fifth year students of Faculty of Education of Suansunandha University who were practicing teaching profession.

Target group used in this research was 11 students of
Faculty of Education of Suansunandha University who were practicing teaching profession in 5 practice schools obtained by using purposing sampling with the researcher as their university supervisor.

\section{A. Variables}

The independent variable was development process of teaching profession of student teachers of Suansunandha University.

\section{B. Dependent Variables}

Ability on learning management of student teachers of Suansunandha University.

\section{Higher Learning Achievement of Classroom Students Taught by the Student Teachers}

Processes used in developing teaching professional skills

Stage 1: Lesson Plan Design and Preparation

Stage 2: Operation according to lesson plan

Stage 3: Assessment of learning management skills' results

Stage 4: Learning effects reflection

Stage 5: Measurement of student's learning achievement

\section{RESEARCH FRAMEWORK AND CONCEPT}

This research have banned on two principles.

1) The learning management skill to student teachers one developed by the collaborative of student teachers, mentor teacher in the school and supervisor from the faculty of education

2) The learning management skill of the teacher are assessed by the learning outcomes of the students.

\section{RESEARCH PROCESSES}

\section{A. Stage 1}

The target group determined by the researcher for this research was 11 fifth year students of Faculty of Education of Suan Sunandha Rajabhat University who were practicing teaching profession in 2013 Academic Year obtained by using purposing sampling from the students with the researcher as their university supervisor.

\section{B. Stage 2}

1) Action stage of learning management development of student teachers in this stage, the researcher took action with their cooperating teachers, teaching specialists, and student teachers, respectively, as follows:

- Analyze learning management standards and indicators of Office of the Basic Education Commission of Thailand upon the class year of individual teaching of student teachers as follows.

- Prepare lesson plan of learning unit and learning substance classified by each teaching.

- Study all related papers and researches in order to seek for consistent methods for instructional activity management.

- Design/select learning media suitable for student teachers' natures in order to enable them to achieve prescribed learning standards.

- Present the obtained lesson plan to the teaching 
specialists in order to reflect its effects prior practical utilization.

2) Stage of student teacher's performance examination:

- The obtained lesson plan was adopted with student teachers.

- The created lesson plan was used for actual learning activity management (Teaching the Lesson).

- The researcher and the cooperating teachers mutually observed and recorded all data on thinking and response of students, interaction between teachers and student teachers, interaction between students and students, thoroughly, for using as the data for reflecting the lesson in the next stage.

- For reflecting on its effect, the researcher, cooperating teachers, and student teachers mutually discussed and reflected its effect after completing lesson planning as follows:

The student teachers firstly reflected their own effects by emphasizing on success and threats influencing on their goal achievement.

The researcher and university supervisor reflected on its effect by emphasizing on learning management process and student teacher's learning results obtained from recorded observation data.

Comments were given in order to be used as the valuable viewpoint for teacher's contributions leading to improvement of learning management process for achieving their goals.

3) Revising the Lesson.

The lesson/lesson plan was revised based on data obtained from reflecting on its effects that may be involved with adjustment of learning media, learning activities, occurred problems, and questions of each stage, for achieving standards and indicators as follows:

- The effects were reflected through discussion.

- Student teachers reflected their own teaching results.

- Teachers of each subject discussed to reflect the obtained results.

- The specialists on learning management reflected the obtained effects.

- Lesson plan was improved.

4) Reflect its effect from instructional capacity assessment form in each dimension and item.

5) Analyze learning achievement of students from scores measured by the student teachers.

\section{Stage 3: Data Inspection and Collection}

The researcher personally collected data as follows:

1) The instructional capacity assessment form of student teachers was used prior the last stage of teaching professional practice in the second semester during February 24th - March 7th, 2014.

2) The teaching supervision and instructional capacity of each teacher was recorded for 3 times in order to compare their teaching advancement in the second semester.

3) The teaching supervision was concluded in the individual form and in overall picture.

4) The obtained results were inspected and analyzed.

\section{Stage 4: Data Analysis}

In this research, the obtained data was analyzed respectively as follows:
1) Analyze the ability on learning management of student teachers from instructional capacity assessment form of student teachers in 3 dimensions including:

- Lesson plan preparation

- Learning management process

- Learning results measurement and assessment

2) Student's learning achievement.

3) Tools used for collecting and studying data.

- 30 items of instructional capacity assessment form of student teachers.

- 20 items of satisfaction questionnaire on learning achievement of students towards student teachers.

\section{CONCLUSION}

According to the development on lesson plan preparation of student teachers, it was found that their learning management level was higher upon each suggestions providing and effect reflecting. Base on the full score of 50, the student teachers had the average score of advancement at $37.50,42.64$, 46.00, respectively, from score base of pre-development stage at 32.73. This was consistent with prescribed research hypothesis.

1) The development on learning management skills of student teachers enabled student teachers to have higher level of those skills upon each suggestions providing and effect reflecting. Base on the full score of 50, the student teachers had the average score of advancement at 37.55, $43.55,46.64$, with percentage of $70.54,75.10,87.10$, 93.28, respectively, from score base of pre-development stage at 35.27. This was consistent with prescribed research hypothesis.

2) From the development on measurement and assessment skills of student teachers, it was found that their scores were higher upon each suggestions providing and consulting. Base on the full score of 50, the student teachers had the average score of advancement at 34.82, $39.91,45.00$, from score base of pre-development stage at 30.90 , with percentage from 61.80 to be $69.64,79.82$, and 90.00, respectively. This was consistent with prescribed research hypothesis.

3) From the development on learning management skills of student teachers, it was found that three dimensions of learning management skills of student teachers were higher with higher score of lesson plan preparation by $26.54 \%$, higher score of learning management process by $22.74 \%$, and higher score of learning result assessment and measurement by $28.20 \%$. The average percentage of the higher scores of those three dimensions was 28.82 that were consistent with the prescribed research hypothesis.

4) The development on instructional capacity of student teachers regarding lesson plan preparation was consistent with the objective of development of learning management skills of student teachers in cooperative schools with the overall mean score of 4.60 while the results of assessment in each dimension were in high level to the highest level with S.D. at0.63. When considering on the skill details, it was found that the determination of learning results according to the highest mean score of learning standards of basic education 
curriculum at 4.84

5) The development on instructional capacity of student teachers regarding learning management process was consistent with the objective of learning management skills of student teachers in cooperative schools with the overall mean score of 4.50 while the results of assessment in each dimension were in high level to the highest level with S.D. at 0.63. When considering on the skill details, it was found that the highest mean of determination of learning results according to learning standards of basic education curriculum was the usage of sound level, interesting tone, and clear explanation, with the mean of 4.66 and S.D at 0.69 while the mean of the usage of emotional maturity and psychology on proper learning management was at 4.66 with S.D at 0.56 .

6) The development on instructional capacity of student teachers regarding learning management process was consistent with the objective of learning management skills of student teachers in cooperative schools with the overall mean score of 4.50 while the results of assessment in each dimension were in high level to the highest level with S.D. at 0.63. When considering on the skill details, it was found that the mean of definition on characteristics demanded for measuring as the behaviors of learners was at 4.66 with S.D at 0.67 while the mean of the building of measurement tools suitable with target group of learning process was 4.66 with S.D. at 80 , the mean of determination of criteria for estimating the data obtained from proper measurement was 4.66 with S.D. at 0.69 , the mean of post-learning testing and learning results reflecting for learner's acknowledgement was 4.66 with S.D. at 0.71 , and the mean of diagnosis and decision by comparing with the prescribed criteria according to the standards was 4.66 with S.D. at 0.5.

\section{DISCUSSION}

According to the development of learning management skills of student teachers, the obtained results were discussed as follows:

1) The development of lesson plan skills of the student teachers provided good results to the student teachers as follows:

The student teachers were able to plan their lesson plan more efficiently because the supervision was operated mutually by the researcher, cooperating teachers, professional teachers, and students and the learning standards and indicators of each subject of each year class of student teachers were analyzed. In addition, the evidences of learning results of the student teachers were also analyzed prior the lesson plan was designed in order to select the learning media and plan the learning process to suit with natures of learners. After designing the lesson plan, its quality was inspected by the teaching specialists in order to listen to their suggestions and the student teachers must always understand and prepare their own lesson plan. This was consistent with the design of teaching supervision format development of Wichira Kruekam-ai.

2) The efficiency of the development of learning management skills of the student teachers was in high level because the researcher and cooperating teachers had to observe and record the observation during the teaching period. After completing the teaching, they had to reflect its effects by starting from self-reflection of the student teachers. Subsequently, cooperating teachers and researcher reflected the results of their observation prior providing discussion and suggestions for improving lesson plan and activities in the next period. This was consistent with the research of Kru Pom 11-9-51 (www.Saruthipong.com accessed on July 28th, 2014) stated that reflecting of its effect was originated from collecting basic data for thorough analysis and consideration leading to actual understanding on one's mind prior expressing it through speaking or writing. As a result, the researcher considered that it was the important method to enable student teachers to improve themselves through thorough understanding.

3) The efficiency of the development of learning result measurement and assessment of student teachers was in high level because the design of measurement and assessment was various and actual by considering on standards and indicators including observation, examination, inspection, and activities, as well as the presentation of student teachers' contributions. As a result, the learning achievement of student teachers met with the established goals. This was consistent with the research of Chinopat Bhummirat (2011: Preface) stated in Standards based Assessment that the Standards based Curriculum established learning standards as the goals of learner quality development and the learning standards specified what the learners should know and behave.

\section{ACKNOWLEDGMENT}

This research was supported by Suan Sunandha Rajabhat University. Special thanks you to all experts and students of SSRU who helped and supported this project.

\section{REFERENCES}

[1] Office of the National Education Commission, Indicators of the Child Center Instruction, Bangkok: Instructional Development Center, 1998.

[2] Bureau of Standards and Education, Approaches to Teaching Program, Ministry of Education, 1999

[3] Suansunandha Rajabhat University, Curriculum of Education Course, Bangkok: Office for Education, 2003.

[4] Bureau of Standards and Education, Approaches to Teaching Program, Ministry of Education, 1008.

[5] Office for Educational Reform, Educational Reform According to National Education Act B.E. 2542, Bangkok: Office for Educational Reform.135, 2001

[6] C. Bhummirat. (2011). The Seminar on Education Reform Policy of Thailand. [Online]. Available: http://www.onec.go.th

[7] Office of Rajabhat University Council, "Teacher production standards," Faculty of Education, Rajabhat University, Bangkok: S \& G Graphic, 2002.

[8] K. Pom. (2014). [Online]. Available: www.Saruthipong.com

[9] W. Kruekam-ai, "The development of supervision model for student teachers to develop competency-based learning that encourages students to thinking," Bangkok, 2009.

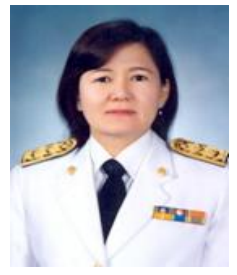

Kancheera Onkwanmoung was born on October 1, 1958, in Chachoengsao, Thailand. She got her education master of higher education in Srinakharinwirot University. She is now working at Suansunandha Rajabhat University.

Ms. Kancheera Onkwanmoung's research experience and interests are in classroom research on teaching and learning development. 